\title{
The first imported human infestation with Furuncular myiasis in man in the Slovakia and current knowledge of myiasis
}

\author{
Totkova $\mathrm{A}^{1}$, Jakubovsky $\mathrm{J}^{2}$, Totka $\mathrm{A}^{3}$, Bohmer $\mathrm{D}^{1}$, Stankovic $\mathrm{I}^{4}$, Holeckova $\mathrm{K}^{4}$, Malova $\mathrm{J}^{1}$, Cibulkova $\mathrm{A}^{5}$ \\ Institute of Medical Biology, Genetics and Clinical Genetics, Faculty of Medicine Comenius University \\ and University Hospital Bratislava, Slovakia. anna.totkova@fmed.uniba.sk
}

\begin{abstract}
INTRODUCTION: Furuncular myiasis is caused by the genus of botfly Dermatobia hominis. It belongs to the family Cuterebridae and is indigenous to Central and South America.

OBJECTIVE: to present a case report of the first case of this disease in Slovakia.

CURRENT STATE OF PROBLEM SOLUTION: The term myiasis refers to infestation of the host (animal, man) by botfly larvae. Its larvae burrow under the skin. They feed on the host's living tissues and fluids.

MATERIAL AND METHODS: Patient's history analysis, parasitological examination.

RESULTS: A 58-year-old woman after returning from Central America found in the skin above her m. gluteus mayor 2 indurations, which contained three botfly larvae. DISCUSSION: Infestation with botfly larvae Dermatobia hominis is for man annoying and from a health point of view dangerous.

CONCLUSION: With proper diagnosis, it is possible to remove the larvae safely from furuncles. The authors point to the first case of imported infestation with Furuncular myiasis caused by botfly Dermatobia hominis in man introduced to Slovakia. They note that increasing tourism spread to the countries with the endemic occurrence of Furuncular myiasis will cause its higher prevalence also in Central European countries (Fig. 5, Ref. 45). Text in PDF www.elis.sk.

KEY WORDS: Central and South America, Furuncular myiasis, larva, botfly, Dermatobia hominis, tourism.
\end{abstract}

\section{Introduction}

The term myiasis refers to affecting the host (animal or man) with botfly larvae Dermatobia hominis. Its larvae burrow under the skin. They feed on the host's living tissues and fluids. It results in the onset of a disease - Furuncular myiasis (Clyti et al, 2008, Pastor et al, 2013).

The human botfly Dermatobia hominis (Greek $\delta \varepsilon \dot{\rho} \mu \alpha$, skin + Bíos, life, and Latin hominis, of a human) is one of several species of fly. Its larvae parasitize humans and many animals, including other primates. It is also known as the "torsalo" or "American warble fly" (Otranto 2007, family Oestridae). It has been shown that eggs of this kind of botfly are vectored by over 40 species of mosquitoes, flies and one species of tick. By its frontal legs, the female of Dermatobia hominis attaches itself to other two-winged insects, which feed on sweat by licking or on blood by sucking (e.g. mosquitoes, biting flies, etc.). Then the female fly lays as many as

\footnotetext{
${ }^{1}$ Institute of Medical Biology, Genetics and Clinical Genetics, Faculty of Medicine Comenius University and University Hospital Bratislava, ${ }^{2}$ Institute of Histology and Embryology FM CU Bratislava, ${ }^{32}$ nd Clinic of Gynaecology and Obstetrics FM CU and UH Bratislava, ${ }^{4} \mathrm{Clinic}$ of Infectology and Geographic Medicine FM CU and UH Bratislava, and ${ }^{5}$ Institute of Foreign Languages FM CU Bratislava, Slovakia
}

Address for correspondence: A. Totkova, RND, $\mathrm{PhD}$, Institute of Medical Biology, Genetics and Clinical Genetics, Faculty of Medicine Comenius University and University Hospital Bratislava, Spitalska 24, SK-813 72 Bratislava, Slovakia.
40 eggs on their body. Eggs are attached with "transparent orange" glue-like substance, which air-dries quickly (Cogley and Cogley, 1989). The entry point of larvae for sucking the vector is the area of penetration and blood sucking, or licking the sweat. Due to heat radiation from the invaded host, the young first-instar larvae quickly leave the envelope of eggs through an operculum and burrow in the site of penetration/bite in the skin and under the skin within 5-10 minutes. Larvae grow under the skin for nine weeks. Mature thirdinstar larvae leave the host body via an opening in the skin through which larvae breathe. They drop to the ground and pupate in the soil. Their development in the soil requires several weeks. Adult botflies are large bumble bee-like flies. They are easily recognized because they lack mouthparts (as is true of other oestrid flies).

The term myiasis refers to infestation of a living body of mammals (animals or humans) by parasiting botfly larvae that burrow under the skin, where they grow and feed on host fluids and living tissue (Hohenstein et al, 2004). Although flies are attracted by open wounds, urine, or hairs soaked with faeces, some species (including the most common myiasis flies, botflies, blowflies and screwflies, feeding on carcasses) may infestate unbroken skin. Non-myiasis flies (e.g. housefly) are considered to be vector agents of these parasites. Colloquialisms for myiasis include "flystrike" and "blowfly strike" and the tissue may be described as fly-blown (contaminated with eggs of myiasis). The name of the disease derives from ancient Greek $\mu$ vía (myia), meaning "fly".

Dermatobia hominis is native to South and Central America, from southeastern Mexico to northern Argentina and Uruguay 
(Otranto, 2007, Pastor et al, 2013). Nevertheless, it is not abundant enough (or harmful enough) ever to attain the true pest status. Botfly larvae can survive the entire 9-week development only if the wound does not become infected. They rarely occur in persons having already experienced infections. The immune system of such subjects kills the larva without removing it completely. It is even possible that the botfly itself may produce antibiotic secretions that may prevent infection. However, their nature is still unknown (Orkiszewski, 2007, Kawabata et al, 2010).

Because some animals (particularly domestic animals) cannot react to the parasite as effectively as humans can, such infestations present a severe and continuing problem for livestock industries worldwide, causing also severe economic losses (Otranto, 2007). Although typically a far greater issue for animals, myiasis is also a relatively frequent affliction of humans in rural tropical regions where two-winged insects thrive (mosquitoes, biting flies, etc.), serving for transmission of botfly eggs (Pastor et al, 2013). Treatment of myiasis may often require medical attention to remove surgically the parasite larvae (Ting and Barankin, 2008, Seilmaier et al, 2011).

In contrast to $D$. hominis, in other species, female botflies lay eggs with a projecting ovipositor on host hairs. The eggs develop into the first-instar larvae within 3-5 days. Mouth hooks and enzymes secreted by larvae aid the larvae to penetrate actively under the host skin. Larvae of the Oestromyiinae subfamily remain under the skin on the site of invasion; they do not migrate. Warbles with larvae are the most frequently located on the legs of animals. Larvae of the Hypodermatinae subfamily penetrate into the skin on the abdominal part of the host. Larval migration lasts over weeks to months. They migrate to the subcutaneous connective tissue towards the back of the host, where they remain and at the end of winter form typical botfly warbles. By secreting enzymes on the site of parasiting, the larvae corrode the tissue and form a hole through the skin for breathing. Within the subcutaneous warble, the larvae undergo 2 molts up to the third-instar. Mature larvae are $30-\mathrm{mm}$ long. By means of their enzymes, the third-instar larvae corrode the host skin and emerge from the breathing pore in the skin. They fall to the ground and pupate in the soil. Adult flies emerge from the pupae in 40-60 days. During warm days, they are immediately ready to mate (Chroust et al, 2001).

More detailed general information on internal and external anatomy of insects is available on many internet sites, e.g. http:// en.wikipedia.org/wiki/Insect_morphology, or in textbooks of entomology. Information provided is general and does not further focus on the species of Dermatobia hominis. Only Baker et al (1995) deals with the subject more closely.

Dermatobia hominis (syn. Dermatobia cyaniventris) is a 1012-mm long fly. It has a yellowish head, dapple-blue thorax, and a metallic blue abdomen. During the time of egg-laying a female attaches itself by its frontal legs to other two-winged insects, which feed on sweat by licking or on blood by sucking (mosquitoes, biting flies, etc.). Then the female fly attaches a group of its eggs on any body part of this captured insect (Volf, Horák et al, 2007, Totková et al, 2008). Embryonic development in eggs takes about 8-11 days.
The first-instar larvae leave egg envelopes once the carrier (vector) attacks the body of its suitable host (man or another mammal). The larvae quickly burrow into the skin, under the skin, and even enter through clothing (Totková et al, 2008). The first-instar larvae have a body with a bulbous end. After molting they develop to the second-instar larvae. It has a bottle-like shape. Its sections of the posterior end are heavily sclerotized. A mature third-instar larva is cylinder-shaped with branched posterior spiracles. The surface of segmented body is covered with numerous small backward projecting spines (Szpila et al, 2014)

Larval development depends on temperature, and takes 5-10 weeks. Once the third-instar larva grows to $25 \mathrm{~mm}$ of size, it leaves the furuncle and pupates in the soil. Finally, in several weeks, the imago emerges from the pupa (Totková et al, 2008, Pastor et al, 2013).

A botfly larva of $D$. hominis can develop virtually anywhere on the human body. It depends only on the site where the biting fly or mosquito has sucked the blood. Botfly larvae may migrate into the nose, eyes, mucosa, and even cause cerebral myiasis (Šerý et al, 1998, Denion et al, 2004, Price et al 2007, Totková et al, 2008).

There are only three fly species that are obligate agents of $f u-$ runcular myiasis in humans and animals (livestock): a single species of flesh fly, Wohlfahrtia magnifica (Sarcophagidae), and two species of blowflies, Chrysomya bezziana and Cochliomyia hominivorax (Calliphoridae). Szpila et al (2014) thoroughly described the morphology of the first-instar larva with light and scanning electron microscope. The following structures are documented: pseudocephalon, antennal complex, maxillary palpus, oral ridges, thoracic and abdominal spinulation, spiracular field, posterior spiracles and cephaloskeleton. New diagnostic features drawn from the cephaloskeleton and the spinulation of abdominal segments, including the anal pad, are discovered. According to them, the relatively distant taxonomic position of all three species is evidence that obligatory myiasis has arisen independently, and the morphology in the first-instar larvae of Chrysomya bezziana, Cochliomyia hominivorax and Wohlfahrtia magnifica is extensively similar in comparison to necrophagous species. At the same time, they provide an identification key for the first-instar larvae of all obligatory traumatic myiasis agents of mammals.

\section{Immunity}

Immunity against Dermatobia hominis is particularly discussed in term of vaccines (Bowles et al, 1992). Problems with natural hosts are the reason for using experimental animal models, rabbits in particular. Lello and Boulard (1990) recognize that rabbits immunized with the extract from larvae are capable of presenting immune responses. Antibodies against the first-instar larvae are produced already on day 5 after infestation. Lello and Peracoli (1993) describe local cellular responses of rabbits immunized, or infested with larvae of $D$. hominis. Skin lesions are also reported (Pereira et al, 2001).

\section{Inflammation}

Cutaneous myiasis can be divided into three clinical manifestations: furuncular, creeping (migratory) and wound (trau- 
matic) myiasis (Hall and Wall, 1995). In furuncular and migratory myiasis, larvae penetrate subcutaneous tissue. In traumatic myiasis flies lay larvae into festering wounds, chronic ulcers, or rotting flesh. Invasion of larvae into tissue results in production of furuncles. In affected subjects, furuncles are formed often in the skin of extremities, back, or hair on the head (Heukelbach et al, 2005; Varani et al, 2007). Apart from local manifestations of inflammation, there are reported also systemic inflammatory processes (Otranto, 2007).

\section{Histopathology}

Lello and de Rosis (2003) by their experiment on mice infested with botfly larvae found out that an inflammatory reaction began slowly. The main inflammatory cells in mice, originally not infested with Dermatobia hominis, were neutrophils. Eosinophils were scarce. The reaction progressed with time. A necrotic halo developed around the larva. It contained inflammatory cells surrounded by fibroblasts. The inflammation invaded the adjacent tissue. The inflammatory reaction in mice was intense on the day immediately after reinfestation, the pattern being changed by the presence of a large number of eosinophils. Activated fibroblasts surrounding the necrotic area around the larva appeared in mice 3 days after reinfestation. During infestation of mice in their experiment, Leite et al (2011) describe the inflammatory process 4 days after infestation as discrete. It consisted of a thin necrotic layer around the larva, oedema, many neutrophils, few eosinophil granulocytes, mast cells, and proliferation of fibroblasts. On day 12 after infestation, there was a thicker necrotic layer in comparison to the previous description. There occurred a neoformation of capillaries, proliferation of the endothelium and fibroblasts, and early stages of fibrosis. This histopathological finding was observed over a large area of the lesion on day 20 after infestation. The progressive acute inflammatory process followed a sequence linked to factors such as the size of larva and presence of secretory-excretory products.

Immuno-histological, ultrastructural and morphometric studies of Grogan et al (1987) on cutaneous myiasis due to Dermatobia hominis document in the tissue surrounding the larvae the presence of infiltrate of lymphoblasts, eosinophil granulocytes, activated fibroblasts, mature macrophages, mast cells, plasma and Langerhans cells. It indicates a complex interactive immunologic response to the botfly parasites. Immunotyping reveals that the dominant dermal cells are activated ( $\mathrm{Ia}+$ ) T-helper cells. The strikingly elevated T-helper/T-suppressor cell ratio might suggest a monoclonal infiltrate. A mixture of Leu $8^{+}$and Leu $8^{-}$ T-cells indicates both immunoregulatory subsets of T-helper cells as found in a reactive process. By electron microscope, there were detected the nuclei in fibroblasts with signs of metabolic activity.

\section{Genetics}

"Myiasis-causing flies" is a generic term that includes species from numerous dipteran families, mainly Calliphoridae and Oestridae. The most important among them are blowflies, botflies, and screwworm flies. This group of flies is characterized by the ability of their larvae to develop in animal flesh. When the host is a live vertebrate, such parasitism by dipterous larvae is known as primary myiasis. Myiasis-causing flies can be classified as saprophagous (free-living species), facultative or obligate parasites. Many of these flies are of great medical and veterinary importance in Brazil because of their role as key livestock insect-pests and vectors of pathogens. In addition, they are considered important legal evidence in forensic entomology (Lima de Azeredo-Espin and Lessinger, 2006). The characterization of myiasis-causing flies by means of molecular markers to study mtDNA (by RFLP) and nuclear DNA (by RAPD and microsatellite) has been used to identify the evolutionary mechanisms responsible for specific patterns of genetic variability. Thus, they analysed population structures of the New World screwworm fly Cochliomyia hominivorax and the botfly Dermatobia hominis. At the beginning of the develpment of genetic analyses there are known some partial results, which are published by e.g. Otranto et al (2003). These authors describe molecular characterization of the mitochondrial cytochrome oxidase I gene of botfly species from Oestridae family.

Heukelbach et al (2005) deal with the differences among larvae of Calliphoridae, Sarcophagidae and Oestridae families according to location in the host body - biology, pathogenesis, and immune responses of hosts to infestation with larvae. Correlations between myiasis caused by larvae and their hosts are largely dependent upon the level of host immunity and ability of larvae to cope with it.

In terms of evolution, myiasis-causing larvae have formed biological, physiological and also biochemical strategies in order to adapt to host immune responses, either nonspecific (NK cells, complement proteins) or specific (antibodies and T lymphocytes). The complexity of mechanisms by which the larvae suppress the immune functions of the host indicates that the host is specifically adapted to the presence of parasites; "in the host" there are not only the passive signs of injury present. Immune functions of their hosts indicate that they are specifically adapted to the presence of parasites in their body regarding their health condition, host's response to myiasis as well as to biology of larvae, site of parasiting, nature of antigen and specific immune defence mechanism of larvae.

\section{Enzyme characterization}

Brant et al (2010) report on a progressive increase in protease activity from first- to third-instar larvae. They reveal a predominance of metalloproteases in first-instar of excretory/secretory products (ESP) that can be related to skin penetration and diversion of host immune response. The predominance of serine proteases in second- and third-instar and the great tryptic activity presented third-instar are attributed to an increasing trophic activity by the growing larvae, since the viability of adult flies strictly depends on larval abilities to assimilate nutrients from the host. Their results suggest that Dermatobia larvae secrete or excrete different proteases that may be related to diverse functions during host penetration and infestation by larvae, which reinforces the relevance of the study of such proteolytic properties. 


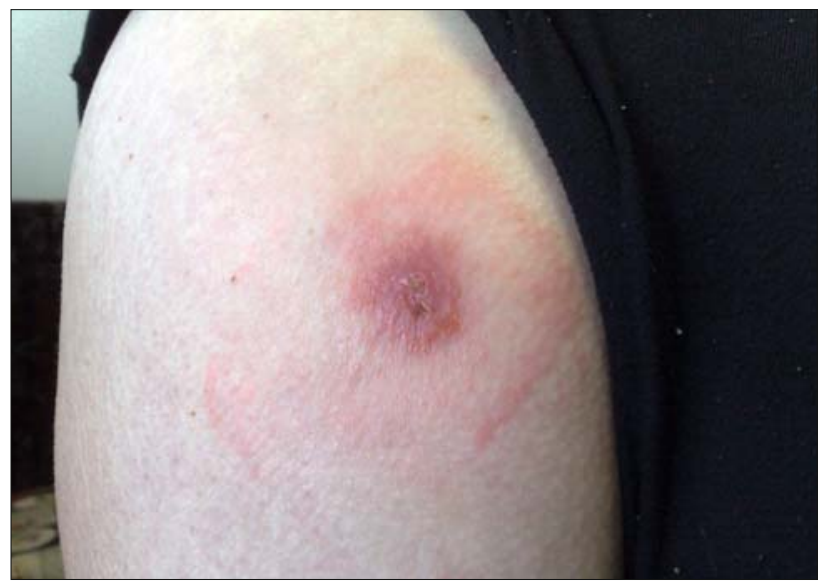

Fig. 1. Furuncular myiasis in regio glutealis lateris sinistri - proximal region - furuncle $2 \mathrm{~cm}$ in diameter with the central opening, around which the skin is of deep-red colour, $5 \mathrm{~cm}$ in diameter with the edges of stiff structure, slightly elevated above the wound surface.



Fig. 2. Dermatobia hominis - second-instar larva, $1 \mathrm{~cm}$ long, yellowish colour - ventral side of the body with dark brown spines in the circumference. The larva was removed from the furuncle in the proximal left gluteal area.

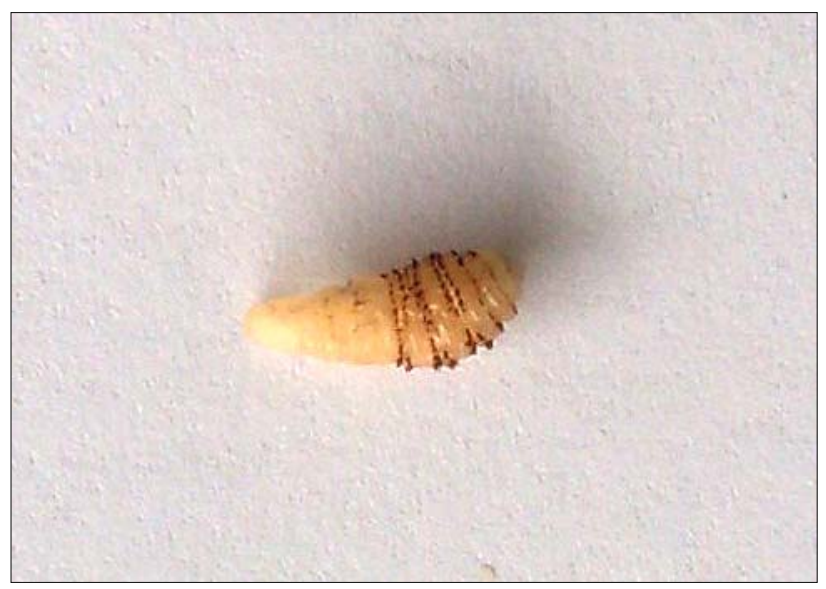

Fig. 3. Dermatobia hominis - bottle-like shape of the body of the secondinstar larva with numerous dark brown spines in the circumference - dorsal side of the body.

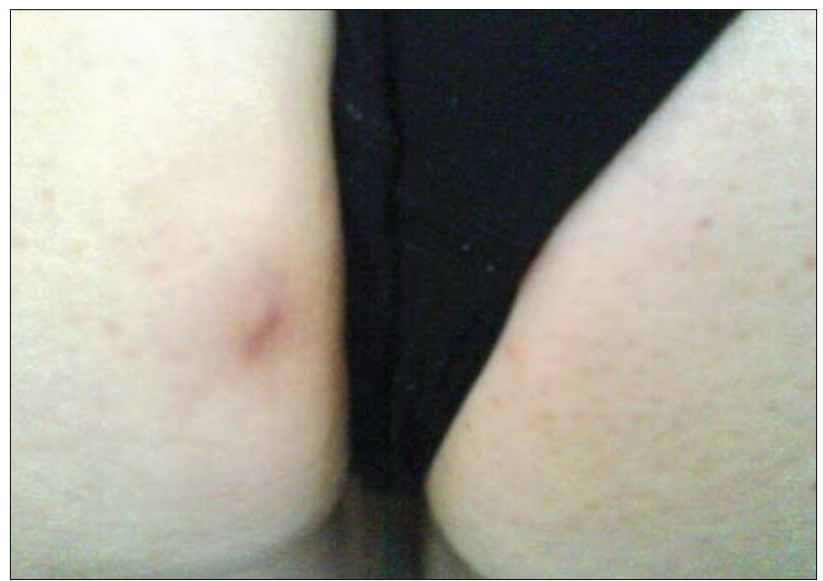

Fig. 4. The condition after treatment and after removing one botfly larva Dermatobia hominis in the lower left gluteal area - infected site healed first.

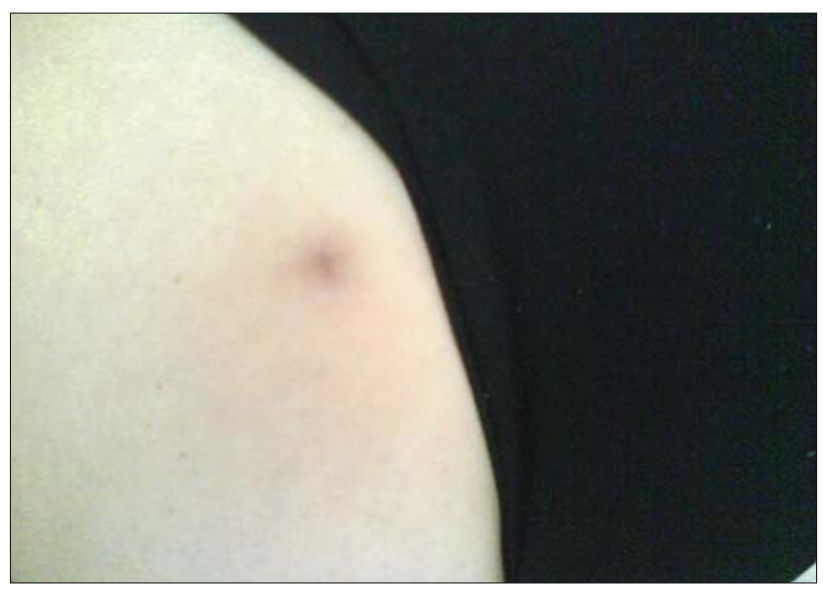

Fig. 5. The condition after treatment and removing two botfly larvae Dermatobia hominis in the upper left gluteal area - infected site fully healed not until two months.

\section{Case report}

\section{Geografic history}

After her tourist travel to Central America and her last stay in Panama, a patient came back to Slovakia in August. She lived in Bratislava. On the last day of the trip, 27th August 2011 she stayed in a hotel in Panama. She slept with her window open. She was wearing only a short light silk nightie. A mosquito net did not protect her bed. In the morning when she got up, she started to feel annoying itching on her left gluteus. When observing herself in a mirror she noticed two reddened sites hard to the touch (in the proximal and distal gluteal area). The rashes looked like mosquito bites.

Personal history: A 58-year-old woman. She did not report any health problems from the past. 
Presenting complaint: After returning home in the beginning of September 2011, she noticed two itching reddened nodules in the left gluteal area. She took antihistamines against itching, but with no improvement. Later, upon the advice of her friend, she treated the affected sites with applying dressings from lily flowers soaked in alcohol. She covered them with gauze and sealed up with sticking plaster. The problems were still increasing. It had already been lasting for 6 weeks. During night and day, she felt like "something was moving" inside the affected sites. She noticed that sometimes slightly turbid, whitish, viscid fluid was flowing out from those sites. In the middle of both reddened sites, a small skin lesion was developing (furuncle). While removing the dressing from the "upper furuncle" she saw a projecting "worm". After removing the "worm" from the wound she brought it to the outpatient department of the Clinic of Infectology and Geographic Medicine of the Faculty of Medicine, Slovak Medical University and University Hospital in Bratislava on October 11, 2011. A removed worm is $1 \mathrm{~cm}$ long. The worm was sent for further special examination to a parasitologist.

\section{Status presens localis}

In regio glutealis lateris sinistri there were visible two skin lesions (proximally and distally), each $2 \mathrm{~cm}$ in diameter (furuncles) on the patient's skin. The skin around the furuncles was of deep red colour, $5 \mathrm{~cm}$ in diameter with the edges of stiff structure, slightly elevated above the wound surface (Fig. 1). Being diagnosed with Larva migrans cutanea, the woman was referred to a surgical treatment to the non-state outpatient department of surgery-traumatology, Teaching Hospital with Outpatient Department of Academic Dérer in Bratislava, to MUDr. Ernest Mäsiar. On October 12, at this department, another larva was removed (by incision with evacuation) from the distal "furuncle meat". The site of larva removal was treated by lavage, drainage and dressing. The patient was put on oral antibiotics claritromycin for bacterial infection. On the next day at the check up and redressing in the surgical outpatient office, another larva was extirpated from the proximal furuncle. The affected area was repeatedly treated with lavage, drainage and dressing. The patient had altogether 2 larvae in the proximal furuncle and 1 larva in the distal one. The follow-up treatment of the wound with lavage lasted two more weeks at the surgical outpatient office until it closed. Antihelminthic therapy with vermox (mebendazol) $3 \times 200 \mathrm{mg}$ was prescribed to complete the treatment. The furuncle in the lower left gluteal area (Fig. 4) healed sooner than the one in the upper region. The latter one was fully healed not until the beginning of December (Fig. 5).

\section{Parasitological examination}

Larva was examined under binocular microscope (magnifier). Larval body is bottle-like shaped, has 9 segments and is of yellow-brown colour. On the surface of the body on the circumference of segments, there are backward projecting spines of dark brown colour that encircle the thorax. The last segments are heavily thickened; the larval body is $1 \mathrm{~cm}$ long (Figs 2, 3). On the frontal part of the body there are 2 mouth hooks visible. Other 2 hooks are visible on the distal end of the body (Figs 2, 3).
Conclusion: It is the second-instar botfly larva of Dermatobia hominis (Figs 2, 3).

\section{Discussion}

Infestation with botfly larvae Dermatobia hominis is not only annoying for humans, but from the health point of view also dangerous. With proper diagnosis, it is possible to remove the larvae from furuncles surgically (Clyti et al, 2008, Seilmaier et al, 2011). However, the simplest method is asphyxiation of the larva in the furuncle (Brewer et al, 1993, Bhandari et al, 2007), as it was done in the reported case, although the patient had no knowledge what the matter was. Some authors advise to asphyxiate the larvae in furuncles by means of covering the air opening with a thick layer of peanut butter, vaseline, or using nail polish (Brewer et al, 1993, Liebert a Madden, 2004, Marty a Whiteside, 2005, Bhandari et al, 2007). The affected area is covered with gauze and sticked with adhesive plaster. After 24 hours, the gauze is removed and the larva, which had tried to wriggle out in order not to be asphyxiated, can be easily extracted using a pair of tweezers. Treatment with lily flowers has been known since ancient times (www.sarahjanecovey.co.uk/flower-meanings). The surgical intervention for treating the infestation with larvae of Dermatobia hominis is unnecessary. However, in indicated cases it cannot be avoided (Denion et al, 2004, Passos et al, 2004, 2008). In either case, it is important to carefully remove the larva from the furuncle entirely without destroying it. If any damage occurs and its parts remain in the furuncle, this can lead to secondary bacterial infection. Dermatobia hominis also infests domestic livestock (cattle, sheep, goats, horses), or wild animals (monkeys, rodents and birds) (Clyti et al, 2008). In view of the fact that recently the medical literature has been updated with information on another vector of myiasis, common house fly (Musca domestica) (Singh et al, 1979, Ferraz et al, 2010, Dehghani et al, 2012, Kumar and Gupta, 2012, Shakeel et al, 2013, Tomy and Prabhu, 2013, Parwani et al, 2014, Yadav et al, 2014), it should be understood that the spread of the disease can occur also in Europe. So far the problem has been reported particularly on the Indian subcontinent. Also Pica et al (2008) report a case of cutaneous furuncular myiasis in a patient admitted to hospital in Rome (Italy). The patient had a subclavicular furuncular skin lesion. After surgical removal of a larva, parasitological examination identified the larva as Cordylobia spp. from Calliphoridae family. The patient was infected during a few-week mission trip (Cameroon, Africa). This case demonstrates that also in Europe we are going to face more frequently the encounters with furuncular myiasis in subjects returning from regions with endemic presence of Cordylobia spp. (Africa).

\section{Conclusion}

More frequent occurrence of Furuncular myiasis should be considered particularly in patients who present in their history to have travelled to endemic countries with the occurrence of myaisis-causing botflies, as it was also in our case. It is possible to see 


\section{$321-327$}

the furuncle which has a central pore that intermittently exudes serosanguinous discharge and protrusion of the breathing tube of the larva can be observed with the aid of a magnifying glass. After establishing the proper diagnosis, the larvae can be removed surgically or asphyxiated and then manually removed. The follow-up treatment includes thorough cleansing of the affected area after removing the larvae followed by administration of antibiotics to prevent secondary bacterial infection.

Up to now, there have been reported only 2 cases of imported infestation of furuncular myiasis in man caused by larvae of Dermatobia hominis in Central European countries, namely in the Czech Republic and Austria. In other countries such as Poland, Hungary, and Croatia, so far there has been no case of dermatobiosis published yet. Thus, it is important not to neglect this parasitosis in differential diagnosis.

Due to increasing tourism extended also to the regions with endemic occurrence of furuncular myiasis, we should increasingly expect various infestations to be imported into Europe, including Slovakia, as in the case presented.

\section{References}

1. Baker DJ, Kantor GR, Stierstorfer MB, Brady G. Furuncular myiasis from Dermatobia hominis infestation. Diagnosis by light microscopy. Am J Dermatopathol 1995; 17 (4): 389-394.

2. Bhandari R, David PJ, Photini S. Furuncular myiasis caused by Dermatobia hominis in a returning traveler. Am J Trop Med Hyg 2007; 76 (3): 598-599.

3. Bowles VM, Grey ST, Brandon MR. Cellular immune responses in the skin of sheep infected with larvae of Lucilia cuprina, the sheep blowfly. Vet Parasitol 1992; 44 (1-2): 151-162.

4. Brant MP, Guimarães S, Souza-Neto JA, Ribolla PE, Oliveira-Sequeira TC. Characterization of the excretory/secretory products of Dermatobia hominis larvae, the human bot fly. Vet Parasitol 2010; 168 (3-4): 304-311.

5. Brewer TF, Wilson ME, Gonzalez E, Felsenstein D. Bacon therapy and furuncular myiasis. JAMA 1993; 270 (17): 2087-2088.

6. Clyti E, Pages F, Pradinaud R. Update on Dermatobia hominis: South American furuncular myiasis. Med Trop 2008; 68 (1): 7-10.

7. Cogley, TP \& MC Cogley. Morphology of the eggs of the human bot fly, Dermatobia hominis (L. Jr.) (Diptera, Cuterebridae) and their adherence to the transport carrier. Int Insect Morphol Embryol 1989; 18 (5/6): 239-248.

8. Dehghani R, Sedaghat M, Bidgoli MS. Wound Myiasis due to Musca domestica (Diptera: Muscidae) in Persian Horned Viper, Pseudocerastes persicus (Squamata: Viperidae). J Arthropod Borne Dis 2012; 6 (1): 86-89.

9. Denion E, Dalens PH, Couppie P, Aznar C, Sainte-Marie D, Carme B, Petitbon J, Pradinaud J, Gerard M. External ophthalmomyiasis caused by Dermatobia hominis. A retrospective study of nine cases and a review of the literature. Acta Ophthalmol Scand 2004; 82 (5): 576-584.

10. De Lello E, Boulard C. Rabbit antibody responses to experimental infestation with Dermatobia hominis. Med Vet Entomol 1990; 4 (3): 303-309.

11. Ferraz AC, Proença B, Gadelha BQ, Faria LM, Barbalho MG, Aguiar-Coelho VM, Lessa CS. First record of human myiasis caused by association of the species Chrysomya megacephala (Diptera: Cal- liplioridae), Sarcophaga (Liopygia) ruficornis (Diptera: Sarcophagidae), and Musca domestica (Diptera: Muscidae). J Med Entomol 2010; 47 (3): 487-490.

12. Grogan TM, Payne CM, Payne TB, Spier C, Cromey DW, Rangel C, Richter L. Cutaneous myiasis. Immunohistologic and ultrastructural morphometric features of a human botfly lesion. Am J Dermatopathol 1987; 9 (3): 232-239.

13. Hall M, Wall R. Myiasis of humans and domestic animals. Adv Parasitol 1995; 35 (4): 257-334.

14. Heukelbach J, Walton SF, Feldmeier H. Ectoparasitic infestations. Curr Infect Dis Rep 2005; 7 (5): 373-380.

15. Hohenstein EJ, Buechner SA. Cutaneous myiasis due to Dermatobia hominis. Dermatology 2004; 208 (3): 268-270.

16. Chroust K, Svobodová V, Modrý D, Volf J. Veterinární arachnoentomologie. Brno: Ústav parazitologie VFU Brno, 2001.

17. Kawabata T, Mitsui H, Yokota K, Ishino K, Oguma K, Sano S. Induction of anti-bacterial activity in larvae of the blowfly Lucilia sericata by an infected environment. Med Vet Entomol 2010; 24 (4): 375-381.

18. Kumar V, Gupta SM. Umbilical myiasis in a neonate. Paediatr Int Child Health 2012; 32 (1): 58-59

19. Leite AC, Nascimento MF, Leite LH, Leite VH. Histopathology of experimental myiasis in mice as a result of infestation and experimental implantation of Dermatobia hominis larvae. J Med Entomol 2011; 48 (3): 680-686.

20. Lello E, de Rosis AM. Inflammatory reaction to the human bot-fly, Dermatobia hominis, in infested and reinfested mice. Med Vet Entomol 2003; 17 (1): 55-60.

21. Lello E, Peraçoli MT. Cell-mediated and humoral immune responses in immunized and/or Dermatobia hominis infested rabbits. Vet Parasitol 1993; 47 (1-2): 129-38.

22. Liebert PS, Madden RC. Human botfly larva in a child's scalp. J Pediatr Surg 2004; 39 (4): 629-630.

23. Lima de Azeredo-Espin AM, Lessinger AC. Genetic Approaches for Studying Myiasis-causing Flies: Molecular markers and mitochondrial genomics 2006; 126 (1-2): 111-131

24. Marty FM, Whiteside KR. Images in clinical medicine. Myiasis due to Dermatobia hominis (Human Botfly). N Engl J Med 2005; 352 (23): e21.

25. Orkiszewski M. Maggots of Lucilia sericata in treatment of intractable wounds. Wiad Lek 2007; 60 (7-8): 381-385.

26. Otranto D. A case of furuncular myiasis associated with systemic inflammation. Parasitol Int 2007; 56 (4): 330-333.

27. Otranto D, Traversa D, Guida B, Tarsitano E, Fiorente P, Stevens JR. Molecular characterization of the mitochondrial cytochrome oxidase I gene of Oestridae species causing obligate myiasis. Med Vet Entomol 2003; 17 (3): 307-315

28. Parwani RN, Patidar KA, Parwani SR, Wanjari SP. Exuberant Oral Myiasis Caused by Musca domestica (Housefly). J Glob Infect Dis 2014; 6 (1): 35-38.

29. Passos MRL, Barreto NA, Varella RQ, Rodrigues GH, Lewis DA. Penile myiasis: a case report. Sex Trans Infect 2004; 80 (3): 183-184.

30. Passos MR, Ferreira DC, Arze WN, Silva JC, Passos FD, Curvelo JA. Penile myiasis as a differential diagnosis for genital ulcer: a case report. Braz J Infect Dis 2008; 12 (2): 155-157. 
31. Pastor C, Briceato G, Schafer F. Cutaneous furuncular myasis caused by Dermatobia hominis. Rev Med Chil 2013; 141 (8): 1081-1082.

32. Pereira MC, Leite VH, Leite AC. Experimental skin lesions from larvae of the bot fly Dermatobia hominis. Med Vet Entomol 2001; 15 (1): 22-27.

33. Pica R, Castellano C, Pignata D, Ipri D. Human cutaneous myiasis: a case report. Clin Ter 2008; 159 (6): 431-433.

34. Price KM, Murchison AP, Bernardino CR, Kang SJ, Grossniklaus HE. Ophthalmomyiasis externa caused by Dermatobia hominis in Florida. Br J Ophthalmol 2007; 91 (5): 695.

35. Seilmaier M, Ehlert N, Fenzl T, Frühwein N. Furuncles on the scalp after a trip to Brazil. Dtsch Med Wochenschr 2011; 136 (7): 309-312

36. Shakeel M, Khan I, Ahmad I, Iqbal Z, Hasan SA. Unusual pseudomyiasis with Musca domestica (housefly) larvae in a tracheostomy wound: a case report and literature review. Ear Nose Throat J 2013; 92 (7): E38-E41.

37. Singh D, Bajaj A, Singh M. Larval conjunctivitis. Indian J Ophthalmol 1978; 26 (1): 51-53.

38. Szpila KM. Hall JR, Wardhana AH, Pape T. Morphology of the first instar larva of obligatory traumatic myiasis agents (Diptera: Calliphoridae, Sarcophagidae) Parasitol Res 2014, 10.1007/s00436-014-3808-x.
39. Šerý V, Bálint O. Tropická cestovní medicína. Praha: Medeon s.r.o, 1998, 569 pp.

40. Ting PT, Barankin B. Cutaneous myiasis from Panama, South America: case report and review. J Cutan Med Surg 2008; 12 (3): 133-138.

41. Tomy RM, Prabhu PB. Ophthalmomyiasis externa by Musca domestica in a case of orbital metastasis. Indian J Ophthalmol 2013; 61 (11): 671-673.

42. Totková A, Klobušický M, Valent M. Lekárska parazitológia. Učebnica pre lekárske a nelekárske študijné programy. Martin: Osveta s.r.o, 2008, 400 pp.

43. Varani S, Tassinari D, Elleri D, Forti S, Bernardi F, Lima M, Tursini S, Sambri V, Otranto D. A case of furuncular myiasis associated with systemic inflammation. Parasitol Int 2007; 56 (4): 330-333.

44. Volf P, Horák P et al. Paraziti a jejich biologie. Praha: Nakladatelství TRITON, 2007, 318 pp.

45. Yadav S, Tyagi S, Kumar P, Puri N. Oral myiasis involving palatal mucosa of a young female. J Nat Sci Biol Med 2014; 5 (1): 194-197.

Received July 3, 2015. Accepted September 14, 2015. 